\title{
THE CONTRIBUTION OF RADIOCARBON DATING TO NEW WORLD ARCHAEOLOGY
}

\author{
R E Taylor \\ Radiocarbon Laboratory, Department of Anthropology, Institute of Geophysics and Planetary Physics, \\ University of California, Riverside, California 92521 USA. Email: retaylor@ citrus.ucr.edu.
}

\begin{abstract}
When introduced almost five decades ago, radiocarbon $\left({ }^{14} \mathrm{C}\right)$ dating provided New World archaeologists with a common chronometric scale that transcended the countless site-specific and regional schemes that had been developed by four generations of field researchers employing a wide array of criteria for distinguishing relative chronological phases. A topic of long standing interest in New World studies where ${ }^{14} \mathrm{C}$ values have played an especially critical role is the temporal framework for the initial peopling of the New World. Other important issues where ${ }^{14} \mathrm{C}$ results have been of particular importance include the origins and development of New World agriculture and the determination of the relationship between the western and Mayan calendars. It has been suggested that the great success of ${ }^{14} \mathrm{C}$ was an important factor in redirecting the focus of American archaeological scholarship in the 1960s from chronology building to theory building, led to a noticeable improvement in US archaeological field methods, and provided a major catalyst that moved American archaeologists increasingly to direct attention to analytical and statistical approaches in the manipulation and evaluation of archaeological data.
\end{abstract}

\section{INTRODUCTION}

The aim of this discussion will be to summarize the most important contributions that ${ }^{14} \mathrm{C}$ age determinations have made in understanding the process and pace of culture development of human societies in the Western Hemisphere. In reviewing these contributions, it might be helpful to note several conceptual and historical factors that condition how ${ }^{14} \mathrm{C}$ values have been employed in New World archaeological studies in comparison and contrast to their utilization in other areas of the world.

First of all, the entire period of human occupation of the Western Hemisphere involves the activities of anatomically modern Homo sapiens sapiens. With few exceptions, no competent researcher has proposed the existence of any pre-sapiens hominids in the New World. The consideration by paleoanthropologists of the chronological problems and issues involving the geochronology of Pleistocene fossil hominids are exclusively the province of the students of Old World archaeology. Secondly, with one major exception, pre-Columbian New World societies did not possess textual-based records that survived for modern scholars to examine and thus there were no historical-based chronological systems to which archaeological features could be associated. The great exception is the textual tradition created by priestly elites of the Maya of the Yucatan Peninsula of ancient Mesoamerica (Mexico). Except for this textual corpus and the corpus of codicies that record pictographically events occurring in the few centuries before European contact in central Mexico, several other areas of ancient Mesoamerica and in a few other areas in the Americas, materials recovered through archaeological excavations provide the sole data base on which the reconstruction of the cultural history of the pre-European societies of North and South America can be based. In this sense, with the exceptions noted, New World archaeological studies have been undertaken within the intellectual contexts involved in the examination almost exclusively of nonhistoric or prehistoric societies.

This has meant that, following the introduction of ${ }^{14} \mathrm{C}$ dating, the most straightforward unit of New World archaeological chronology could have been expressed simply in "radiocarbon time" as in BP (before present), which will be followed in this discussion. This is in contrast to European practice, where chronology building included direct links to the historic chronologies of the circum Mediterranean and Near Eastern civilizations conditioned a need to convert ${ }^{14} \mathrm{C}$-based BP into calendar-based AD/BC units. It is true that New World archaeologists, in many cases, have followed the practice of converting $\mathrm{BP}$ to $\mathrm{AD} / \mathrm{BC}$ units, perhaps influenced by the early editorial practice of Radiocarbon. This was necessary for the southwestern United States where comparisons with den- 
drochronological data was required, and in eastern Mesoamerica where comparisons with Maya long count calendar based chronologies existed. However, in light of the subsequent calibration problems, in all other areas of the New World, it might have been prudent, from the beginning, to have represented their chronologies exclusively in radiocarbon time.

Finally, as discussed in detail elsewhere (Taylor 2000a), an important feature of the development of professional prehistoric archaeological studies in the United States has been its 20th century development while almost entirely embedded within the American anthropological tradition. This characteristic is in significant contrast to the conceptual, intellectual, and organizational environment that developed autonomous prehistoric archaeological disciplinary traditions in England, other European nations, and academic traditions based on European models such as that which developed in Canada and South America.

The final years of the 20th century mark the completion of five decades of the use of ${ }^{14} \mathrm{C}$ dating in New World archaeology. As James Arnold, one of the two coworkers with Willard F Libby (19081980 ) in the initial development of the ${ }^{14} \mathrm{C}$ method, many years later remarked (Arnold 1992:3), the origin of ${ }^{14} \mathrm{C}$ dating could be set as early as 1946 - the date of the first paper on "radiocarbon" (Libby 1946)—or as late as 1951—the first published ${ }^{14} \mathrm{C}$ date list (Arnold and Libby 1951). If an actual "birthday" for ${ }^{14} \mathrm{C}$ dating is desired, it might be identified as the day on which the first ${ }^{14} \mathrm{C}$ "date"-an Egyptian archaeological sample—was actually calculated. This was July 12, 1948 (J R Arnold and E C Anderson, personal communication 1996).

\section{Radiocarbon Dating: An Archaeological "Atomic Bomb"}

An American archaeologist who quickly became associated with Libby in introducing the ${ }^{14} \mathrm{C}$ method to his colleagues, the late Frederick Johnson (1904-1994), once remarked that ${ }^{14} \mathrm{C}$ dating dropped the equivalent of an "atomic bomb" on archaeology in the late 1940s (Johnson 1965:762). His initial comments were focused on North American archaeology, but he also later applied it to the whole of the Western Hemisphere (MacNeish 1996).

Johnson was in an excellent position to evaluate the initial impact of ${ }^{14} \mathrm{C}$ dating on New World archaeology both to his peers within Americanist Archaeology and to archaeologists dealing with Old World issues and topics. He had served as the president of the Society for American Archaeology in 1946-1947 and, beginning in 1947, prepared an annual report on American archaeology for the American Journal of Archaeology. In 1950, Johnson reported that some of initial set of dates:

agree fairly well with established ideas, others indicate that archaeological guesses. . . while perhaps of the right order, relatively, are nowhere near the actual age . . In some cases they seem to contradict what has been assumed to the "fact" based on stratigraphy, and in other cases they necessitate drastic revision of present conceptions (Johnson 1950:236).

Throughout the 1950s, Johnson $(1951,1952,1955)$ would provide the most authoritative and informed commentaries on the increasing corpus of ${ }^{14} \mathrm{C}$ values and reflections on their increasingly important role in the derivation of temporal relationships in New World archaeological studies. He recorded the initial resistance of a number of American archaeologists to what was perceived in some quarters as a "threat of the atom in the form of radiocarbon dating" who then added that "this may be our last chance for old-fashioned, uncontrolled guessing" (Phillips et al. 1951:455). Johnson recalled the "frequent howls of protests, often savagely derogatory" (quoted in Marlowe 1999:22) as various ${ }^{14} \mathrm{C}$ results diffused through the North American archaeological fraternity and reported that: 
Libby's proposal to provide a new means of counting time, one which promised a definable degree of accuracy and world-wide consistency, caused all sorts of consternation. The idea that the method of dating was derived from nuclear mysteries . . . converted surprise to fright, and sometimes even panic (Johnson 1965:762).

A summary of the ${ }^{14} \mathrm{C}$ values determined at the University of Chicago laboratory during the period of its operation (Table 1) reveals that archaeological samples constituted more than $60 \%$ of the total. Of the archaeological samples, about $70 \%$ were from New World sites.

It appears that the initial reaction of a number of New World archaeologists to the introduction of ${ }^{14} \mathrm{C}$ dating was not that different from how it was initially received in certain quarters in European archaeology (e.g. Neustupny 1970). One difference appears to be that very little documentary evidence of the most hostile and derogatory comments from New World prehistoricans has survived—most of it being transmitted only orally in informal gatherings. Johnson reported that there was an unconfirmed rumor that a scientist who once proclaimed that "radiocarbon dating would never work" had later destroyed incriminating correspondence (F Johnson, personal communication 1986).

Table 1 Chicago ${ }^{14} \mathrm{C}$ determinations: discipline and region ${ }^{\mathrm{a}}$

\begin{tabular}{lllll}
\hline & \multicolumn{3}{c}{ Discipline } \\
\cline { 2 - 4 } Region & Archaeology & Geology & Other $^{\text {b }}$ \\
\hline Western Eurasia (Near East) & 33 & - & - & {$[9 \%]$} \\
Western Europe & 7 & 10 & - & {$[5 \%]$} \\
England & 4 & 14 & - & {$[5 \%]$} \\
North America & 128 & 78 & 21 & {$[60 \%]$} \\
Mesoamerica (Mexico) & 21 & 5 & - & {$[6 \%]$} \\
South America & 18 & 4 & 5 & {$[6 \%]$} \\
Other & 31 & 2 & - & {$[9 \%]$} \\
& $242[63 \%]$ & $113[30 \%]$ & $26[7 \%]$ & \\
\hline
\end{tabular}

a Total $\mathrm{N}=381$ (Libby 1955)

${ }^{\mathrm{b}}$ Maize, tree rings, guano

${ }^{\mathrm{c} J a p a n, ~ S u b-S a h a r a n ~ A f r i c a, ~ H a w a i i, ~ A u s t r a l i a ~}$

In the mid-1960s, Johnson (1965) commented that the impact of ${ }^{14} \mathrm{C}$ on the archaeology of the Western Hemisphere was most significant in resolving the chronology dealing with antiquity of New World human populations, the age of the Adena and Hopewell cultures of the Ohio valley, the beginnings of New World agriculture, and the correlation of the Maya calendar with the Western calendar. He also noted that, in his view, the "inevitable period of readjustment following the initial hue and cry [when ${ }^{14} \mathrm{C}$ dates were first introduced] brought about a reappraisal of the archaeological evidence" in a number of sites. In this connection, he commented that:

This return to the trenches for a new and more careful look, often for the purpose of proving the radiocarbon dates to be erroneous and useless, resulted in a refinement of methods of recording in the field to in order to determine more precisely associations of samples with levels. We may not realize it now, but possibly this need for detailed and accurate record of the provenience and associations of samples has resulted in material improvement of archaeological field methods (Johnson 1965:764).

By the time of Johnson's 1965 commentary, which appeared as an article in the first international radiocarbon conference proceedings volume (Chatters and Olson 1965), ${ }^{14} \mathrm{C}$ dating can be said to have fully emerged from its pioneering phase. The period of initial suspicion and even, in some quar- 
ters, hostility (F Johnson, personal communication 1986) which questioned the general, overall validity of the ${ }^{14} \mathrm{C}$ method in toto were, with few exceptions, now silent and discussion turned to questions of the accuracy and precision of ${ }^{14} \mathrm{C}$ values from specific archaeological or geological contexts. The journal Radiocarbon (originally the Radiocarbon Supplement to the American Journal of Science) was now in its seventh volume. By this time, more than $20{ }^{14} \mathrm{C}$ laboratories had been established in all parts of the world. In the United States, at three of these laboratories-at the Universities of Arizona, Michigan, and Pennsylvania—archaeologists were instrumental in their establishment.

\section{CULTURAL SEQUENCE TO CHRONOMETRIC AGE}

The effects of the introduction of ${ }^{14} \mathrm{C}$ data into North American archaeological studies dealing with the development of the various culture histories varied depending on several factors but among the most important were the traditions that had developed in different regions of North America among area specialists prior to the advent of ${ }^{14} \mathrm{C}$ method. Johnson's list of important issues that ${ }^{14} \mathrm{C}$ data was of particular importance- the age of the Adena and Hopewell cultures of the Ohio valley, the beginnings of New World agriculture, and the correlation of the Maya calendar with the Western calendar-will be considered in this section. We will consider the influence of ${ }^{14} \mathrm{C}$ dating in studies concerning the early peopling of the New World in a separate section since New World Paleoindian archaeology transcends regional considerations.

\section{Eastern North America}

James Griffin, the archaeologist who had developed the first major pre- ${ }^{14} \mathrm{C}$ synthesis of Eastern US prehistory (Griffin 1946 [actually written 1937]), was directly involved as a central figure in the introduction and articulation of ${ }^{14} \mathrm{C}$ data into the existing matrix of North American archaeology with particular focus on Eastern North American (Griffin 1952, 1967; Stoltman 1978). Griffin was also largely responsible for the development of the University of Michigan ${ }^{14} \mathrm{C}$ laboratory, one of the pioneering ${ }^{14} \mathrm{C}$ facilities in the United States which, throughout its more than 20-yr history (19501972), focused its attention on archaeological samples.

Just as ${ }^{14} \mathrm{C}$ dating was being introduced, Griffin (1952), and Griffin together with Philip Phillips and James Ford (Phillips et al. 1951), had undertaken a review of the chronology for the ceramic periods of the Lower Mississippi Valley. While their analysis pushed back the Mississippian and early ceramic complexes of the region to close to the ages indicated by the first set of ${ }^{14} \mathrm{C}$ values for the region, Griffin (1978:55) would later comment that ${ }^{14} \mathrm{C}$ values:

altered many of the earlier interpretations of the temporal position of a large number of the cultural complexes recognized by archaeologists. Probably the most important changes have been within the time period attributed to the Archaic cultures, but all other periods have also been affected by the more accurate temporal assessments provided by radiocarbon.

One of the most surprising results of ${ }^{14} \mathrm{C}$ dating was the age of the fiber-tempered pottery in southeastern United States in the Savannah River area and in northeastern Florida. The earliest pottery appears about $4500 \mathrm{BP}$ in Georgia and about $4000 \mathrm{BP}$ in Florida. ${ }^{14} \mathrm{C}$ dating contributed significantly to eliminate the possibility of a Eurasiatic origin for Eastern Woodland pottery (Griffin 1968).

Much interest and initial controversy surrounded the dates associated with two complexes associated with burial mounds in the Ohio Valley and adjacent areas. The temporal relationship of Adena and Hopewell and how ${ }^{14} \mathrm{C}$ data were to be interpreted in attempting to resolve their chronological relationship occupied the attention of archaeologists in the region for several decades. As was the case in several other regions (e.g. initial ${ }^{14} \mathrm{C}$ dates dealing with Maya long-count calendar), initial 
age determinations prompted much consternation as the temporal priority of Adena was called into question. It took more than a decade for the difficulties to be at least partly resolved with the recognition of the lack of association of samples with their alleged archaeological contexts, distinctions between burial and village manifestations, and the temporal overlap between Adena and Hopewell in some areas.

The advent of agriculture in the Eastern United States had been an important regional horizon marker since the absence or presence of agriculture had been a principal feature that initially served to differentiate the Archaic from the later Woodland and Mississippian periods. There had been a tendency for some to claim agriculture as an independent invention in the region, but none of these suggestions could stand as more and more ${ }^{14} \mathrm{C}$ values modified views as to the "first" occurrence of different cultigens in the region. In the 1980 s, AMS-based ${ }^{14} \mathrm{C}$ values on carbonized fragments of squash (Cucurbita sp.) confirmed its occurrence in Archaic period deposits in Illinois at about 7000 BP. By contrast, AMS analysis of fragmentary remains of maize (Zea mays) previously dated at about $2000{ }^{14} \mathrm{C}$ yr on the basis of associated organics determined that the actual age of the maize itself was about $1500 \mathrm{BP}$ at one site. In one case, the maize fragments were determined to be modern contamination (Conrad et al. 1984). However, later studies also using AMS technology to obtain direct dates on maize determined that it was present in Middle Woodland period about 2000 BP in the upper Mississippi River valley (Riley et al. 1994).

Accelerator mass spectrometry (AMS)-based ${ }^{14} \mathrm{C}$ determinations were also used to document conclusively the indigenous occurrence of a North American plant thought by some to have been introduced at the time of European contact. Individual seeds of Corispermum L. were analyzed to eliminate the problems of stratigraphic mixing and late Pleistocene/early Holocene ages were obtained on four specimens (Betancourt et al. 1984). Likewise, AMS-based analysis directly on samples of common beams (Phaseolus vulgaris) from sites in the Northeastern United States determined their occurrence in the region not earlier than about 650 BP (Hart and Scarry 1999) in contrast to earlier ${ }^{14} \mathrm{C}$ values on purportedly associated charcoal (Richie 1969).

\section{Western North America}

Like many areas of the New World, chronological understandings concerning the prehistoric cultures of Western North America can, with justification, be divided into "pre- ${ }^{14} \mathrm{C}$ " and "14 C" eras. Although early excavations in Lovelock Cave, Nevada benefited from the introduction of statigraphic strategies introduced by N C Nelson, until the late 1940s, with few exceptions, the majority of the archaeology conducted by those with various levels of training and experience focused on artifact collecting. Chronological relationships were initially structured by comparing Great Basin materials with those from other regions, most notably, the Southwest (Heizer and Hester 1978). However, a focal feature of traditional chronology building in the Great Basin has been the use of projectile points as time markers and much interest was focused at the time of the introduction of ${ }^{14} \mathrm{C}$ - which continues to the present - on the relationship of various dated series - mostly in caves and rock shelters-with the various regional projectile point series (Hester 1973). This is of particular importance in a region where most sites are surface features and the projectile points themselves are the sole means of establishing temporal control.

An important theme in Great Basin archaeology has been various views concerning various lengthy abandonment(s) of parts of the region. In some versions, this argument was associated with arguments concerning the date of the introduction of the bow and arrow to the region. Region-wide abandonment was first postulated to coincide with the Altithermal, a period of decreased effective moisture dated to between about 7000 and 4500 BP (Baumhoff and Heizer 1965). Other interpreters 
suggested human abandonment of the entire eastern Great Basin between about 3200 and 1500 BP (Madsen and Berry 1975). A significant element in the arguments supporting such a view are interpretations of ${ }^{14} \mathrm{C}$ dates and associated cultural materials in a series of caves and rock shelter contexts. A critique of this view notes that the use of ${ }^{14} \mathrm{C}$ values for such purpose is usually very problematical in part due to the differential availability of datable materials from closely spaced levels in sites and the high cost of obtaining sufficient ${ }^{14} \mathrm{C}$ analyses to permit the secure documentation of any such hiatus context (Aikens 1976).

Great Basin and California archaeology has yielded a number of case studies of the effect of the loss of stratigraphic association for samples in cave and rock shelters that can occur both during occupation as well as after the abandonment of sites. An example of such a problem is illustrated by the ${ }^{14} \mathrm{C}$ analysis of materials from Gypsum Cave, Nevada. Atlatl shaft fragments and dung from an extinct giant ground sloth were found in apparent association. An early ${ }^{14} \mathrm{C}$ date obtained by the Chicago laboratory on the dung determined it age to be approximately 10,000 BP. This value was used to infer an age for the atlatl fragments (Libby 1952). More than a decade later (Berger and Libby 1967),

a ${ }^{14} \mathrm{C}$ analysis directly obtained on one of the atlatl shafts determined that their age to be about 3000 BP.

The same difficulty was encountered in determining the age of fragments of atlatl dart shafts that had been recovered from Potter Creek Cave in northern California in the early part of this century. The dart shaft fragments were originally thought to have been contemporaneous with extinct Pleistocene fauna found in the cave. The ${ }^{14} \mathrm{C}$ age of the atlatl shaft fragments were later determined to be about 2000 BP indicating at least a 6000-8000-yr temporal hiatus between the extinct fauna and the cultural materials in this cave (Taylor 1975; Payen and Taylor 1977).

For northwestern North America, ${ }^{14} \mathrm{C}$ values provided the chronological definition for a major Holocene time marker used by archaeologists and other Quaternary scientists in the region. A violent eruption of Mount Mazama in the southern Oregon Cascade range, one of the largest eruptions of the late Quaternary, distributed volcanic ash from central Nevada to British Columbia (Bacon 1983). The event has been characterized by mineralogical analysis of tephra sediments in many archaeological sites, geological contexts and lake sediment cores throughout the region. A recent review of the ${ }^{14} \mathrm{C}$ determinations associated with the eruption have identified 65 values obtained by 16 laboratories over the last five decades (Hallet et al. 1997:Table 1). Critical reviews of this data place it within a century of $6800 \mathrm{BP}$ with one investigator calculating $6845 \pm 50 \mathrm{BP}$ (Bacon 1983) and a second $6730 \pm 40 \mathrm{BP}$ (Hallet et al. 1997). The second value has reportedly been supported by data from the Greenland GISP2 ice core on the basis of a correlation with a $\mathrm{SO}_{4}$ peak thought to be associated with the eruption (Zdanowicz et al. 1999:623).

The usefulness of the Mount Mazama eruption event as a regional time marker is illustrated in the determination that the Kennewick, Washington human skeleton was associated with sediments below the Mazama ash lens. On this basis, the age of $8410 \pm 60 \mathrm{BP}$ (Table 5), assigned to Kennewick on the basis of a direct ${ }^{14} \mathrm{C}$ age determination on bone (Taylor et al. 1998), is consistent with its stratigraphic relationship to the Mount Mazama event.

\section{Southwestern United States}

In the early part of the 20th century, the American Southwest became a focal point of New World archaeological studies. An important factor was that the region enjoyed one of the earliest applications of stratigraphic excavation strategies in the New World combined with typological and seriation approaches to the temporal analysis of ceramics and other artifact types. Several other factors 
contributed to this status, but, of these, probably the most important was that for North America north of Mexico the region enjoyed the most secure prehistoric chronometric framework in the pre- ${ }^{14} \mathrm{C}$ period. This was due, to a considerable extent, to the extensive and sophisticated development of dendrochronological applications.

Dendrochronology was developed and applied in the Southwest by an astronomer, Andrew Ellicott Douglass, more than two decades prior to the development of the ${ }^{14} \mathrm{C}$ method. Because of the effectiveness of dendrochronological approaches for the last two millennia - the period beginning with Basket Maker II on the Colorado Plateau and Mogollon I for central Arizona and New Mexico- ${ }^{14} \mathrm{C}$ data was not aggressively pursued for Pueblo, Mogollon and Hohkam sites and materials. However, ${ }^{14} \mathrm{C}$ data were employed in Southwestern subregions where dendrochronology could not be reliably extended—such as the southern Arizona Desert-and for "Archaic cultures" in excess of about 2000 BP (Rohn 1978).

Of early significant interest was the Chicago ${ }^{14} \mathrm{C}$ date of about $5900 \mathrm{BP}$ determined on charcoal from a lower level in Bat Cave, New Mexico, purportedly associated with early forms of domesticated maize (Dick 1965). From the beginning, the results were suspect or, as Frederick Johnson termed it, "tenuous," because of problematic associations, even suggesting that the date should not have been published (Johnson 1955:154). Since that time, attempts to date the arrival of maize and other cultigens in the Southwest have been controversial (Simmons 1986). The development of AMS ${ }^{14} \mathrm{C}$ technology applied resulted in a set of results that have been obtained directly on the cultigens rather than on associated organics. An excellent example of the effects of direct dating of the domesticates in contrast to earlier ${ }^{14} \mathrm{C}$ dates on associated organics is available from the experiences at the Fresnal Shelter in southern New Mexico (Tagg 1996). Minnis (1992), and Hard and Roney (1998) recently assembled the results of such direct dating at sites in Arizona, Utah, New Mexico, and Chihuahua, Mexico. Currently, the earliest reliable evidence for cultigens in this region is about 3000 BP with maize, beans, and one species of squash arriving first.

\section{Mesoamerica}

Other than the southwestern United States, ancient Mesoamerica-a region in pre-Hispanic times that encompassed the southern two thirds of the modern state of Mexico and most of what is now central America-was the object of the most intensive study by a number of archaeologists and other scholars from universities, museums, research foundations both the United States and Europe. The initial major attraction beginning in the 19th century was a series of sites particularly in the Maya region of the Yucatan peninsula containing extensive ruins of large monumental structures (e.g. Tikal and Copan), in the Valley of Mexico (e.g. Teotihuacan), and Valley of Oaxaca (e.g. Monte Alban). As already noted, the Yucatecan Maya area was the only region in the pre-Columbian New World with a fully formed writing and complex long count calendar system and an extensive inscriptional textual corpus. In the case of the Maya calendar, the long count system involved a continuous recording of days from a fixed zero point. Among the Maya city states of the Yucatan Peninsula, hieroglyphic texts and calendar notations were inscribed on stela and on various structural elements of buildings within temple complexes.

Long count dates were extensively employed in Maya archaeology to associate ceramic types with architectural phases for the Maya Classic period (Fedick and Taube 1992). A long-standing question was the correlation of the pre-Hispanic lowland Maya long count calendar with the Western calendar. At the time of the introduction of the ${ }^{14} \mathrm{C}$ method, the majority of Mayan scholars had tentatively accepted, from a lengthy list of correlation formulas, the "GMT" (Goodman-Martinez-Thompson) 
correlation as best fitting the available evidence, although a correlation formula devised by H J Spinden continued to be cited (Thompson 1960:306-9).

As summarized in Table 2, the first ${ }^{14} \mathrm{C}$ determination bearing on the Maya correlation problem was obtained by the Lamont ${ }^{14} \mathrm{C}$ laboratory on a sample of wood extracted from a wooden lintel inscribed with a Maya long count calendar notation from the Classic Maya site of Tikal in Guatemala (Kulp et al. 1951:566). Surprisingly for many Mayanists, rather than supporting the GMT correlation, the ${ }^{14} \mathrm{C}$ value on the lintel supported the Spinden correlation scheme. This correlation calculated dates exactly $160 \mathrm{yr}$ earlier than did the GMT formula. A second ${ }^{14} \mathrm{C}$ determination on another inscribed wooden lintel from Tikal bearing the same long count data as in the first test was undertaken at Chicago by Libby and also supported the Spinden correlation (Libby 1954:740).

These results were criticized on the basis that they were derived from samples from existing museum collections whose size had been reduced for transport and thus had lost their outside rings (Satterthwaite 1956). The result of these initial results was the first intensive dating program undertaken by a ${ }^{14} \mathrm{C}$ laboratory in conjunction with an major archaeological excavation-in this case at Tikal from $1955-1970$ by the University Museum of the University of Pennsylvania. The first topic addressed was the ${ }^{14} \mathrm{C}$ dating of lintels of temple structures on which were inscribed Maya long count calendar dates. In selecting these samples, there was an explicit recognition of an problem with wood samples containing a number of rings. The issue was first labeled the "post-sample-growth (or inner wood) error" and then renamed, more appropriately, the "pre-sample growth error" (Ralph 1971:4).

New collections of wood samples with due consideration of the problem of missing wood were obtained during the University of Pennsylvania excavations. In a critical interpretation of the resultant ${ }^{14} \mathrm{C}$ data, involving more than 100 determinations obtained by the University of Pennsylvania and UCLA laboratories, the pre-sample growth factor was employed to explain the earlier determinations. By this time, there was the beginnings of an understanding of calibration problems for ${ }^{14} \mathrm{C}$ values. Fortunately, early tree-ring data indicated a close correspondence between ${ }^{14} \mathrm{C}$ and solar time for the critical period at issue (Satterthwaite and Ralph 1960; Ralph 1965). Most, but not all (e.g., Andrews 1978), Mayanists accepted the new ${ }^{14} \mathrm{C}$ results as strongly supporting the GMT correlation (Kelley 1983). In the mid-1960s, the pre-sample growth factor was also invoked to resolve problems of correlating ${ }^{14} \mathrm{C}$ determinations on charcoal with the apparently well-known chronological sequence for the Classic period at Teotihuacan in central Mexico (Kovar 1966).

${ }^{14} \mathrm{C}$ dating was also extensively employed to provide temporal resolution for what some archaeologists considered the "mother culture" (cultura madre) of ancient Mesoamerican civilization-the Olmec_-associated with sites such as La Venta and Tres Zapotes located in the Gulf Coast region of Mexico. Others viewed the Olmecs as contemporaneous with or even to postdate the Classic Maya. A series of ${ }^{14} \mathrm{C}$ values obtained from La Venta demonstrated clearly that the Olmecs at this site predated the Maya by many centuries (Drucker et al. 1957:265). A suite of ${ }^{14} \mathrm{C}$ values obtained during studies at the site of San Lorenzo documented an even earlier Olmec phase reaching back to at least 3000 BP (Coe and Diehl 1980:395-6).

The question of the origins of plant domestication in the New World had been long been centered on Mesoamerica in light of the fact that the wild precursors of the major domesticates-and especially Zea mays - were generally considered to be indigenous to that region. A major excavation in a number of caves and rock shelters in Tehuacan Valley in central Mexico in the 1960s specifically directed at elucidating the course of plant domestication in the region revealed a long stratigraphic record covering most of the Holocene (Byers 1967-1972). Contained in these deposits at various levels were fragments of a number of plant domesticates. A large suite of ${ }^{14} \mathrm{C}$ dates primarily on 
Table $2{ }^{14} \mathrm{C}$ data associated with the correlation of the Maya and Western calendars

A. Initial measurements

\section{Lamont $^{\mathrm{a}}$}

Tikal Structure $10^{\mathrm{b}}$

Spinden $=$ AD 481; GMT $=$ AD 741

$\mathrm{L}-113,1470 \pm 120 \mathrm{BP}(\mathrm{AD} 481 \pm 120)^{\mathrm{c}}$

L-113 bis, $1502 \pm 60$ BP $(\text { AD } 456 \pm 60)^{\text {d,e }}$

Chicago $^{\mathrm{f}}$

Tikal Temple IVg

Spinden = AD 481; GMT $=$ AD 741

C-948, $1485 \pm 120$ BP $(\text { AD } 469 \pm 120)^{\mathrm{h}}$

C-949, $1521 \pm 170$ BP $(\text { AD } 433 \pm 170)^{\mathrm{h}}$

$(\text { Weighted average }=\text { AD } 451 \pm 110)^{\mathrm{h}}$

B. Recognition of "presample tree ring growth error" problem

\section{Pennsylvania ${ }^{\mathrm{i}}$}

Tikal Temple IV

Spinden = AD 435; GMT $=$ AD 712

Average 13 Temple IV ${ }^{14} \mathrm{C}$ values $=1213 \pm 34 \mathrm{BP}(\mathrm{AD} 746 \pm 34)^{\mathrm{j}}$

Tikal Temple I

Spinden = AD 435-452; GMT = AD 695-712

Average 7 Temple I ${ }^{14} \mathrm{C}$ values $=1275 \pm 37 \mathrm{BP}(\mathrm{AD} 684 \pm 37)^{\mathrm{j}}$

Tikal Structure 10

Spinden $=$ AD 481; GMT = AD 741

$\mathrm{P}-293,1353 \pm 57$ BP $(\text { AD } 606 \pm 57)^{\mathrm{j}, \mathrm{k}}$

$U C L A^{1}$

Tikal Temple IV

Spinden = AD 435; GMT = AD 712

Average 2 Temple IV ${ }^{14}$ C values $=1238 \pm 30$ BP $(A D 712 \pm 30)^{\mathrm{m}}$

Tikal Structure 10

Spinden = AD 481; GMT $=$ AD 741

Average 5 Structure $10{ }^{14} \mathrm{C}$ values $=1344 \pm 45 \mathrm{BP}(A D 606 \pm 45)^{\mathrm{n}}$

${ }^{a}$ Kulp et al. (1951)

${ }^{b}$ From American Museum of Natural History, New York

c"AD" value calculated by subtracting BP value from 1951

dBroecker et al. (1959)

eRecount by gas counting of solid carbon sample used for L-113. "AD” value calculated by subtracting BP value from 1958.

fLibby (1955:131)

'From Ethnographical Museum, Basel, Switzerland

h"AD" value calculated by subtracting BP value from 1954

iSatterthwaite and Ralph (1960)

j“AD” value calculated by subtracting BP value from 1959

${ }^{\mathrm{k}}$ Same wood as used for L-113

${ }^{1}$ Fergusson and Libby (1963:13-14)

mDuplicates of 2 Pennsylvania Temple IV wood samples

${ }^{n}$ Duplicates of 5 Pennsylvania Structure 10 wood samples 
associated charcoal provided the chronology for development of domesticated species (Johnson and Willis 1970; Johnson and MacNeish 1972). Charcoal ${ }^{14} \mathrm{C}$ values were used to assign age to the individual fragments of early maize as early as $7000 \mathrm{BP}$. Concerns regarding the association of charcoal with the maize fragments were later addressed when AMS-based ${ }^{14} \mathrm{C}$ measurements on the maize specimens themselves determined that there was a considerable range in the ages of the individual specimens; the oldest exhibited an age of about $4700 \mathrm{BP}$ (Long et al. 1989).

\section{PALEOINDIAN CHRONOLOGY}

One of the longest running and acrimonious debates in New World archaeology concerns the nature and timing of the peopling of the Western Hemisphere (Stanford 1982; Irving 1985; Taylor 1991). There is no question that the advent of ${ }^{14} \mathrm{C}$ dating transformed discussions concerning dating frameworks for Paleoindian sites and contexts (Wilmsen 1965). The history of the application to ${ }^{14} \mathrm{C}$ in Paleoindian studies provides a classic case study of the great impact that the ${ }^{14} \mathrm{C}$ method made in New World archaeology.

The context for 20th century discussions of this issue had their origins in the 1920s and 1930s with the general acceptance of the direct association of two types of fluted projectile points-known as Clovis and Folsom from their type sites-with skeletal remains of an extinct North American megafauna, particularly bison and mammoth. These discoveries convinced the professional archaeological community that human populations had entered the New World sometime between 10,000 and $25,000 \mathrm{yr}$ ago (Wormington 1957). In the pre- ${ }^{14} \mathrm{C}$ era, the range in age assigned to the entry resulted primarily from differences among geologists and others as to the dating of the final phase of the Wisconsin glaciation and the disappearance of the Pleistocene fauna in North America. Also, on stratigraphic criteria, Clovis was demonstrated to predate Folsom but the temporal offset was unknown (Meltzer 1989).

With the advent of ${ }^{14} \mathrm{C}$ dating, one of the first issues for which Chicago ${ }^{14} \mathrm{C}$ dates were obtained was the resolution of the chronological status for the New World Paleoindian period. In pursuing this issue and in later considerations of the question of dating purported pre-Clovis occupations in the New World, a number of major problems that confront the application of ${ }^{14} \mathrm{C}$ in archaeology in general have been addressed and well illustrated. For example, the problem of stratigraphic misattribution of an organic sample (e.g. charcoal) for which a ${ }^{14} \mathrm{C}$ age estimate is obtained and an archaeological or geological context was vividly exemplified in the first ${ }^{14} \mathrm{C}$ age determination on a sample from the Folsom type site in New Mexico. The sample, initially described as charcoal from a fire-pit situated below bison bones and artifacts collected by Harold J Cook in 1933, was dated at $4283 \pm$ 250 BP (an average of two determinations) which generated the comment "surprisingly young" (Arnold and Libby 1950:10). Cook revisited the Folsom site in June 1950 and determined that the "sample had been taken from a hearth in the fill of a secondary channel which had cut through the original deposit of bison bone and artifacts" (Roberts 1951:116). A ${ }^{14} \mathrm{C}$ value of $9883 \pm 350 \mathrm{BP}$ (C-558) was subsequently obtained on burned bison bone from what was interpreted as the Folsom horizon at Lubbock Lake, Texas (Libby 1951:293; Roberts 1951:20-1; Haynes 1982:384).

It thus appears that the first ${ }^{14} \mathrm{C}$ determination concerned with one of the most controversial issues in American archaeology was deemed unacceptable for what it was supposed to have dated, requiring reinterpretation of the geological context and an additional ${ }^{14} \mathrm{C}$ analysis on a sample presumed to be more directly associated with the cultural or technological tradition for which dating was being attempted. It was subsequently argued that the problem may have not been resolved by the Lubbock Lake values. Geological evidence combined with additional ${ }^{14} \mathrm{C}$ data pointed to the conclusion that the burned bone sample used for C-558 did not, in fact, come from the Folsom levels at the 
Lubbock Lake site (Haas et al. 1986; Holliday and Johnson 1986). If this is correct, the first ${ }^{14} \mathrm{C}$ age determination securely associated with Folsom materials was obtained on charcoal collected at the Lindenmeier site in Colorado, where a ${ }^{14} \mathrm{C}$ value of 10,780 $\pm 375 \mathrm{BP}$ was obtained (Haynes and Agogino 1960).

Over the next four decades, a steadily increasing corpus of ${ }^{14} \mathrm{C}$ determinations were obtained on materials variously associated with a number of Clovis and Folsom sites in western North America. Table 3 represents the results of a critical review of ${ }^{14} \mathrm{C}$ values on various sample materials that are in secure stratigraphic relationship with either Clovis or Folsom occupations (Taylor et al. 1996). Based on this data base, Clovis populations hunted and collected on the North American Great Plains from about 11,600 to 10,900 BP, while Folsom groups flourish from 11,000 to 10,250 BP. It appears that the transition from Clovis to Folsom may have occurred within a period of $100 \mathrm{yr}$ or less (Haynes 1984), although the current suite of dates does not have the precision required to test this assertion (Haynes 1991).

Table 3 Selected ${ }^{14} \mathrm{C}$ dates associated with Clovis and Folsom sites in North America (Taylor et al. 1996). When value cited in the table is an average, the number of ${ }^{14} \mathrm{C}$ values averaged are listed in parenthesis.

\begin{tabular}{llll}
\hline Clovis sites & ${ }^{14}$ C age $(\mathrm{BP})$ & Folsom sites & ${ }^{14} \mathrm{C}$ age $(\mathrm{BP})$ \\
\hline Murray Springs (8) & $10,890 \pm 50$ & Hanson (4) & $10,250 \pm 90$ \\
Lehner (12) & $10,940 \pm 40$ & Blackwater Draw (5) & $10,290 \pm 90$ \\
Anzick & $10,940 \pm 90$ & Carter/Kerr McGee & $10,400 \pm 600$ \\
Dent & $10,980 \pm 90$ & Lubbock Lake & $10,540 \pm 100$ \\
UP Mammoth & $11,280 \pm 350$ & Indian Creek/1 & $10,630 \pm 280$ \\
Lange/Ferguson & $11,140 \pm 140$ & Owl Cave & $10,640 \pm 85$ \\
Colby & $11,200 \pm 220$ & Lindenmeier (3) & $10,660 \pm 60$ \\
Domebo & $11,480 \pm 450$ & Agate Basin (2) & $10,700 \pm 70$ \\
Blackwater Draw (3) & $11,300 \pm 240$ & Folsom (6) & $10,890 \pm 50$ \\
Aubrey (2) & $11,570 \pm 70$ & Indian Creek/2 & $10,980 \pm 150$ \\
\hline
\end{tabular}

The central influence of ${ }^{14} \mathrm{C}$ dating on New World Paleoindian studies can be seen most clearly when it is noted that in several cases, a single ${ }^{14} \mathrm{C}$ age determination was the most important factor in directing great attention and relatively massive amounts of resources toward specific sites and regions purported to contain evidence of Paleoindian materials presumed to be older than Clovis. For example, in the early 1960s, the decision to undertake the large scale excavations at Tule Springs, Nevada (Wormington and Ellis 1967) was stimulated in large part by a single ${ }^{14} \mathrm{C}$ determination of >23,000 yr (C-914) obtained by Libby's group (Libby 1952:121) on what was characterized as charcoal recovered from what had been labeled a "hearth-like feature" by excavators who associated its occurrence with sediments containing the bones of extinct fauna (Harrington 1954; Harrington and Simpson 1961).

In another instance, a ${ }^{14} \mathrm{C}$ age of $27,000^{+3000} /{ }_{-2000} \mathrm{BP}$ (Irving and Harrington 1973) was obtained on an inorganic fraction of a bone implement recovered from a locality in the Old Crow Basin, Yukon Territory, Canada in the early 1970s (Irving 1985:547). At both Tule Springs and in the case of the Old Crow artifact, subsequent ${ }^{14} \mathrm{C}$ data determined that the original age assignments for the cultural materials had been greatly inflated. In the case of the Tule Springs materials, the only uncontested artifacts recovered during extensive excavations carried out in the early 1960s were associated with sediments dating in the 10,000-11,000 BP range. The features originally labeled as "hearths" con- 
taining "charcoal" were determined to be concentrations of decayed plant remains associated with water channel or spring deposits (Haynes et al. 1966; Haynes 1988). As for the Old Crow implement, an organic fraction of the bone later yielded a ${ }^{14} \mathrm{C}$ value of $1350 \pm 150 \mathrm{yr}$ (Nelson et al. 1986).

Another type of contamination issue was associated with the ${ }^{14} \mathrm{C}$ dating of "charcoal" materials from the site of Lewisville in Texas. The apparent charcoal had been recovered in the early 1950s from a series of hearth-like features containing extinct fauna that included mammoth and a Clovis-type point. The ${ }^{14} \mathrm{C}$ values ranged between $>37,000$ and $>63,000 \mathrm{BP}$ (Crook and Harris 1958). It was initially suggested that the charcoal derived from packrat middens (Heizer and Brooks 1965). However, renewed excavation in the late 1970s determined that the supposed charcoal used for the ${ }^{14} \mathrm{C}$ determinations was actually lignite, a form of coal.

Studies associated with the Tule Springs, Old Crow, and several other sites illustrate the continuing efforts to bring evidence to bear that would support the validity of the view that human populations occupied the Western Hemisphere prior to the appearance of the Clovis hunters and gatherers. The so-called "Clovis boundary" has been continuously assaulted by a minority of New World archaeologists over several generations and have spurred archaeological investigations from Alaska to Tierra del Fuego. However, of the more than 100 sites in North America that have been reported to contain evidence of "pre-Clovis" occupation, only a relatively small number currently remain under active consideration. Of the remaining alleged pre-Clovis sites in North (Payen 1982; Meltzer 1989) or South (Lynch 1990; Meltzer et al. 1994) America, either the cultural nature of the material or the adequacy of the chronometric data associated with the remains, or both, have been questioned. In most cases, ${ }^{14} \mathrm{C}$ age determinations have been and continue to be the crucial arbiter and standard used in documenting the age of a given feature or site locus purported to represent a pre-Clovis occupation.

Beginning in the early 1970 s, a series of ${ }^{14} \mathrm{C}$ age determinations on human skeletal materials and initial results of the application of two other dating methods-amino acid racemization (AAR) and uranium series (U-series) - to human bone appeared to support a pre-Clovis occupation of the New World. In addition to the ${ }^{14} \mathrm{C}$-based ages on the Los Angeles (>23,000 BP) and Laguna (17,150 BP) skeletons (Berger et al. 1971), AAR-based age estimates assigned ages of 70,000 yr to the Sunnyvale (northern California) skeleton, $>50,000$ to the Haverty or Angeles Mesa skeleton (southern California), 48,000 yr to the Del Mar skeleton (southern California) and, apparently confirming an earlier ${ }^{14} \mathrm{C}$ value, 23,000 $\mathrm{yr}$ for the Yuha skeleton, although U-series indicated an age of about 19,000 $\mathrm{yr}$ (Bada et al. 1974; Bada and Helfman 1975; Bischoff and Childers 1979).

The advent of AMS-based ${ }^{14} \mathrm{C}$ technology made practical an intensive reevaluation of the age estimates obtained on these and other human skeletons. AMS ${ }^{14} \mathrm{C}$ analysis permitted routine ${ }^{14} \mathrm{C}$ analyses of milligram amounts of carbon from highly specific molecular fractions extracted from bone (Stafford et al. 1982, 1990, 1991; Hedges and Law 1989; Hedges and Van Klinken 1992; Taylor 1994, 1997). Table 4 summarizes the results of the direct ${ }^{14} \mathrm{C}$ dating or re-dating by several groups of investigators of bone samples on which previous ${ }^{14} \mathrm{C}$ values had been obtained and/or on which AAR- and U-series-based age estimates had been obtained.

In all cases, there was a significant downward revision in the originally assigned ages (Taylor et al. 1983, 1985; Ennis et al. 1986). Table 5 summarizes directly ${ }^{14} \mathrm{C}$-dated North American human skeletal samples in excess of $8000 \mathrm{BP}$ where there are sufficient technical data available to support the age assignments indicated. Currently, a group of human skeletons recovered from Anzick, Montana with ${ }^{14} \mathrm{C}$ values on amino acid fractions ranging from 10,240 to $10,940 \mathrm{BP}-$ represent the oldest, directly ${ }^{14} \mathrm{C}$-dated example of a New World Homo sapiens sapiens that have to date appeared in published reports. 
Table 4 Revisions in age estimates on human bone (except Old Crow) from North America sites of purported Pleistocene age based on AMS ${ }^{14} \mathrm{C}$ determinations and related data

\begin{tabular}{|c|c|c|c|c|}
\hline \multirow{2}{*}{$\begin{array}{l}\text { Skeleton(s)/ } \\
\text { artifact }\end{array}$} & \multicolumn{2}{|c|}{$\begin{array}{l}{[\mathrm{A}]} \\
\text { Original estimate }\end{array}$} & \multirow{2}{*}{$\begin{array}{c}{[\mathrm{B}]} \\
\text { Revised estimate } \\
\left({ }^{14} \mathrm{C} \text { age }\right)\end{array}$} & \multirow[b]{2}{*}{ Laboratories $^{\mathrm{a}}$} \\
\hline & Basis & Age & & \\
\hline Sunnyvale & $\begin{array}{l}\text { AAR } \\
\text { U-series }\end{array}$ & $\begin{array}{l}70,000 \\
8300 / 9000\end{array}$ & $\begin{array}{l}3600-4850 \\
6300\end{array}$ & $\begin{array}{l}\text { UCR/Arizona AMS } \\
\text { UCSD (Scripps)/Oxford AMS }\end{array}$ \\
\hline $\begin{array}{l}\text { Haverty } \\
\text { [Angeles Mesa] }\end{array}$ & AAR & $>50,000$ & $\begin{array}{l}4050-5350 \\
5200 \\
7900-10,500 \\
2730-4630 \\
4600-13,500^{\mathrm{b}} \\
5250 \\
15,900^{\mathrm{b}}\end{array}$ & $\begin{array}{l}\text { UCR } \\
\text { GX (Geochron) } \\
\text { UCLA } \\
\text { UCR/LLNL-CAMS AMS } \\
\text { UCR/LLNL-CAMS AMS } \\
\text { DSIR, New Zealand AMS } \\
\text { DSIR, New Zealand AMS }\end{array}$ \\
\hline Del Mar & $\begin{array}{l}\text { AAR } \\
\text { U-series }\end{array}$ & $\begin{array}{l}41,000-48,000 \\
11,000 / 11,300\end{array}$ & $\begin{array}{l}4900^{\mathrm{b}} \\
4830 \\
1150-5060^{\mathrm{b}}\end{array}$ & $\begin{array}{l}\text { UCSD (Scripps)/Oxford AMS } \\
\text { Arizona AMS } \\
\text { Arizona AMS }\end{array}$ \\
\hline $\begin{array}{l}\text { Los Angeles } \\
\text { [Baldwin Hills] }\end{array}$ & ${ }_{\text {AAR }}{ }^{14} \mathrm{C}$ & $\begin{array}{r}>23,000 \\
26,000\end{array}$ & & UCR/Arizona AMS \\
\hline Taber & Geologic & $22,000-60,000$ & 3550 & Chalk River AMS \\
\hline Yuha & $\begin{array}{l}{ }^{14} \mathrm{C} \\
\text { AAR } \\
\text { U-series }\end{array}$ & $\begin{array}{l}22,000 \\
23,000 \\
19,000\end{array}$ & $1650-3850$ & Arizona AMS \\
\hline Old Crow & ${ }^{14} \mathrm{C}$ & 23,000 & 1350 & Simon Fraser/McMaster AMS \\
\hline Laguna & ${ }^{14} \mathrm{C}$ & $\begin{array}{r}7100 \\
17,150 \\
>14,800\end{array}$ & 5100 & UCSD (Scripps)/Oxford AMS \\
\hline Natchez & Geologic & "Pleistocene" & 5580 & Arizona AMS \\
\hline Anzick & Clovis & $10,000-11,000$ & $8610-10,680$ & Arizona AMS \\
\hline Tepexpan & Geologic & "Pleistocene" & $920-1980$ & Arizona AMS \\
\hline Calaveras & Geologic & "Pliocene" & 740 & UCR/Arizona AMS \\
\hline
\end{tabular}

aReferences for all values except Calaveras are cited in the caption for Table 25.5 in Taylor (1992); Calaveras data from Taylor et al. (1992)

${ }^{b}$ Experimental osteocalcin fraction with anomalous ${ }^{14} \mathrm{C}$ values (Burky et al. 1998)

Purported pre-Clovis sites that continue to be seriously examined by New World archaeologists have associated with them extensive suites of ${ }^{14} \mathrm{C}$ determinations. In North America, the Meadowcroft Rockshelter in Pennsylvania, a deeply stratified site excavated in the mid-1970s, documented by 52 ${ }^{14} \mathrm{C}$ determinations, has been strongly advanced as a well-documented pre-Clovis occupation. Excavators initially pointed to a ${ }^{14} \mathrm{C}$ value at about $17,000 \mathrm{BP}$ obtained on what was described as a carbonized fragment of cut bark-like material in the lowest cultural unit (Adovasio et al. 1978). More recently, "applying the most conservative interpretation of the $\left[{ }^{14} \mathrm{C}\right]$ data," support for human occupation at Meadowcroft not later than about 14,000 BP has been advanced (Adovasio et al. 1998). A vigorous debate has been carried out (Dincauze 1981) that, on one hand, has raised questions about the potential contamination of samples since a coal-like deposit (vitrinite) is exposed in the rock shelter (Haynes 1980; Mead 1980; Tankersley and Munson 1992) and, on the other, a vigorous defense of the validity of the ${ }^{14} \mathrm{C}$ dates and their association with cultural materials (Adovasio et al. 1980, 1992, 1998). 
Table $5{ }^{14} \mathrm{C}$-dated early Holocene human skeletal samples from North America

\begin{tabular}{|c|c|c|}
\hline Site & Sample/fraction & ${ }^{14} \mathrm{C}$ age $(\mathrm{BP})$ \\
\hline Anzick, Montana ${ }^{\mathrm{a}}$ & $\begin{array}{l}\text { Glycine } \\
\text { Glutamic acid } \\
\text { Hydroxyproline } \\
\text { Gelatin (untreated) } \\
\text { Alanine } \\
\text { Aspartic acid }\end{array}$ & $\begin{array}{l}10,940 \pm 90(\mathrm{AA}-2981) \\
10,820 \pm 100(\mathrm{AA}-2979) \\
10,710 \pm 100(\mathrm{AA}-2980) \\
10,500 \pm 400(\mathrm{AA}-313 \mathrm{~B}) \\
10,370 \pm 130(\mathrm{AA}-2982) \\
10,240 \pm 120(\mathrm{AA}-2978)\end{array}$ \\
\hline Buhl, Idaho ${ }^{\mathrm{b}}$ & Total acid insoluble organics & 10,675 \pm 95 (BETA-43055/ETH-7729) \\
\hline Mostin, California ${ }^{\mathrm{c}}$ & Total acid insoluble organics & $10,470 \pm 490($ UCLA-2171) \\
\hline $\begin{array}{l}\text { On-Your-Knees Cave, Prince } \\
\text { of Wales Island, Alaska }\end{array}$ & Gelatin (XAD treated) & $9730 \pm 60($ CAMS-29873) \\
\hline Gordon Creek, Colorado ${ }^{\mathrm{d}}$ & Total acid insoluble organics & $9700 \pm 250(\mathrm{GX}-0530)$ \\
\hline Spirit Cave, Nevada ${ }^{\mathrm{e}}$ & $\begin{array}{l}\text { Total amino acids } \\
\text { (hair, bone, fiber) }\end{array}$ & $\begin{array}{l}9350 \pm 70(\text { UCR-3261-4/CAMS-12353) } \\
9360 \pm 60(\text { UCR-3261-2/CAMS-12354) } \\
9410 \pm 60(\text { UCR-3324-1/CAMS-24194) } \\
9430 \pm 60(\text { UCR-3260/CAMS-12352) } \\
9430 \pm 70(\text { UCR-3323/CAMS-24199) } \\
9450 \pm 60(\text { UCR-3261-2/CAMS-14224) } \\
9460 \pm 60(\text { UCR-3324-2/CAMS-24197) }\end{array}$ \\
\hline $\begin{array}{l}\text { Wizard Beach, } \\
\text { Pyramid Lake, } \\
\text { Nevada }\end{array}$ & $\begin{array}{l}\text { Total acid insoluble organics } \\
\text { Total amino acids }\end{array}$ & $\begin{array}{l}9515 \pm 155(\mathrm{GX}-19422) \\
9110 \pm 60(\mathrm{UCR}-3445 \mathrm{~A} / \mathrm{CAMS}-26369) \\
9210 \pm 60(\mathrm{UCR}-3445 \mathrm{~B} / \mathrm{CAMS}-26370) \\
9250 \pm 60(\mathrm{UCR}-3445 \mathrm{C} / \mathrm{CAMS}-28124)\end{array}$ \\
\hline $\begin{array}{l}\text { La Brea, } \\
\text { Los Angeles, California }\end{array}$ & Total amino acids & $9000 \pm 80($ UCLA-1292B $)$ \\
\hline Kennewick, Washingtong ${ }^{\mathrm{g}}$ & Total amino acids & $8410 \pm 60($ UCR-3476/CAMS-29578) \\
\hline
\end{tabular}

${ }^{\text {a }}$ Stafford et al. (1990); ${ }^{\mathrm{b}}$ Green et al. (1998); ${ }^{\mathrm{K}}$ Kaufman (1980); ${ }^{\mathrm{d} B r e t e r n i t z ~ e t ~ a l . ~(1971) ; ~}{ }^{\mathrm{e}}$ Kirner et al. (1997); ${ }_{\mathrm{f}}$ Berger et al. (1971); ${ }^{\mathrm{g}}$ Taylor et al. (1998).

Pendejo Cave, New Mexico, with an extensive suite of ${ }^{14} \mathrm{C}$ values documenting more than 55,000 yr of stratified sediments, has been also advanced by its excavators as a site where pre-Clovis occupation has been demonstrated (Chrisman et al. 1996). This view is based, in part, on human skin imprints on clay from different sediment units ranging in age, based on associated charcoal, from 12,000 to $>35,000 \mathrm{BP}$, and the occurrence of a purported human hair samples directly ${ }^{14} \mathrm{C}$ dated at about 12,000 BP. Other investigators have raised a number of questions concerning the relationship of the imprints to the dated sediments and the attribution of the hair as human (e.g. Taylor et al. 1995).

In South America, a set of ${ }^{14} \mathrm{C}$ values have been obtained on various organics from the site of Monte Verde in Chile (Dillehay 1989, 1997). In 1997, a senior group of Paleoindian specialists evaluated the archaeological and geological evidence at the site and reported that the series of ${ }^{14} \mathrm{C}$ values were considered to provide a valid indication of the age of the associated artifacts and other cultural features (Adovasio and Pedler 1997; Meltzer et al. 1997). Attention was particularly focused in ${ }^{14} \mathrm{C}$ values that indicated that human occupation at Monte Verde had begun not later than about 12,500 BPapproximately $1000{ }^{14} \mathrm{C}$ yr earlier than the Clovis occupation in North America. Contamination of samples does not seem to be at issue, and suggestions that there is a major ${ }^{14} \mathrm{C}$ reservoir effect in the region around Monte Verde have not been supported by recent measurements of contemporary organics and consideration of potential sources of magmatic $\mathrm{CO}_{2}$ in the region (Taylor et al. 1999). However, in late 1999, several renewed concerns about Monte Verde, including the integrity of the site 
context, had been expressed (Fiedel 1999) along with vigorous responses by the original site excavators (Collins 1999; Dillehay et al. 1999).

\section{GENERAL IMPLICATIONS}

Many commentators have noted that the most immediate and obvious impact of the ${ }^{14} \mathrm{C}$ method on the conduct of New World archaeological research in general was the ability of the technique to provide chronometric age estimates using - to a first-order approximation-a fixed-rate temporal scale which transcended local, regional, and continental boundaries. In the words of J Desmond Clark (1979:7), without ${ }^{14} \mathrm{C}$ data, archaeologists would continue to "founder . . . in a sea of imprecisions sometimes bred of inspired guesswork but more often of imaginative speculation." His comments reflected his experience in African prehistory, but it can be applied accurately as well in New World studies. It can be legitimately argued that temporal intercomparibility of ${ }^{14} \mathrm{C}$ values were as significant and important a characteristic of ${ }^{14} \mathrm{C}$ values as the degree of their accuracy or precision. Fortunately, the temporal framework itself turned out to be amazingly accurate given the number of assumptions that had to hold to rather narrow ranges.

A somewhat less recognized contribution of ${ }^{14} \mathrm{C}$ data has been the fact that ${ }^{14} \mathrm{C}$-based age estimates provide a means of deriving chronological relationships independently of assumptions about cultural processes and totally unrelated to any type of manipulation of archaeological materials (Willey and Phillips 1958:44; Dean 1978:226; Taylor 1978:63). When pressure to derive chronology primarily from the analyses of artifact data was released, inferences about the evolution of human behavior based on variations in environmental, ecological, or technological factors could be aggressively pursued employing an independent chronological framework. In the United States, the rise of the "new archaeology" in the 1970 s took place in this context. Louis Binford has reflected that ${ }^{14} \mathrm{C}$ chronology "has certainly changed the activities of archaeologists, so that now, in many ways for the first time, they direct their methodological investments toward theory building rather than towards chronology building" (quoted in Gittens 1984:238).

At the inception of the method, Frederick Johnson offered a perspective that was as helpful five decades ago as it is today:

[P]rogress in the development of ... [radiocarbon dating] depends to a large degree upon the character of the collaboration [between archaeologists and other scientists]. The laboratory procedure involves theories in physics and chemistry which for the most part are outside the experience of almost everyone who has a sample to be dated. On the other hand, the results secured are of little consequence unless they are directly or indirectly related to some stratigraphic sequence. The value of the laboratory results is enhanced by critical evaluation by other scientists. Most particularly, the reverse is true. This involves continual examination of all basic theory and hypotheses by everyone concerned. The future value and usefulness of the method depends in large measure upon the success of continued collaboration between physicists, archaeologists, geologists, botanists, and others [Johnson et al. 1951:62].

This injunction assumed a new significance with the introduction of AMS technology. For archaeologists, the increasing utilization of milligram-size samples required an even more rigorous attention to the evaluation of geological, geochemical, and archaeological contexts of samples. The need for interdisciplinary cooperation and collaboration, particularly with geological specialists, has become even more critical as AMS technology assumes an ever-increasing role in the ${ }^{14} \mathrm{C}$ analysis of archaeological and other late Quaternary paleoecological materials over the next decade and beyond. 


\section{CONCLUSION}

The application of the ${ }^{14} \mathrm{C}$ method to archaeological materials is generally considered to be a watershed event in the history of archaeology and, in particular, in prehistoric studies (Taylor 2000b). Perhaps the most forceful statement was the view of the late Glyn Daniel that the development of the ${ }^{14} \mathrm{C}$ method in the 20th century should be equated with the 19th century change in the Western world view that accompanied the revelation of the great antiquity of the human species (Daniel 1959:7980; 1967:266).

Understanding the influence of ${ }^{14} \mathrm{C}$ as being of a "revolutionary" character for aspects of Old World archaeology (Renfrew 1973) is also an accurate representation of its impact on the conduct of New World archaeology over the last half century. That influence has been both obvious and subtle, as well as pervasive and lasting. Radiocarbon dating, which to again quote Frederick Johnson, "dropped like an atomic bomb" on New World archaeology 50 years ago, promises to continue to provide for generations of scholars to come, critical data for those concerned with understanding, from a scientific perspective, the prehistory of the New World.

\section{ACKNOWLEDGMENTS}

The author wishes to acknowledge the generous assistance of the late Frederick Johnson in understanding initial reactions of archaeologists in the United States. The author also wishes to thank the Gabrielle O Vierra Memorial Fund for support. This is contribution 99/4 of the Institute of Geophysics and Planetary Physics, University of California, Riverside.

\section{REFERENCES}

Adovasio JM, Pedler DR. 1997. Monte Verde and the antiquity of humankind in the Americas. American Antiquity 71:573-580.

Adovasio JM, Gunn JD, Donahue J, Stuckenrath, R. 1978. Meadowcroft Rockshelter, 1977: an overview. American Antiquity 43:632-51.

Adovasio JM, Donahue J, Stuckenrath R. 1980. Yes, Virignia, it really is that old: a reply to Haynes and Mead. American Antiquity 45:588-95.

Adovasio JM, Donahue J, Stuckenrath R. 1992. Never say never again: some thoughts on could haves and might have beens. American Antiquity 57:327-31.

Adovasio JM, Pedler DR, Danahue J, Stuckenrath R. 1998. Two decades of debate on Meadowcroft Rockshelter. North American Archaeologist 19:317-41.

Aikens CM. 1976. Cultural hiatus in the eastern Great Basin? American Antiquity 41:543-50.

Anderson DD. 1987. Western Arctic and Sub-Arctic. In: Taylor RE, Meighan CW, editors. Chronologies in New World archaeology. New York: Academic Press. p 29-50.

Andrews EW 5th. 1978. Endnote: The northern Maya lowlands sequence. In: Taylor RE, Meighan, CW, editors. Chronologies in New World archaeology. New York: Academic Press. p 377-81.

Arnold JR. 1992. The early years with Libby at Chicago: a retrospective. In: Taylor RE, Long A, Kra RS, editors. Radiocarbon after four decades: an interdisciplinary perspective. New York: Springer-Verlag. p 3-10.
Arnold JR, Libby WF. 1949. Age determinations by radiocarbon content: checks with samples of known age. Science 110:678-80.

Arnold JR, Libby WF. 1950. Radiocarbon dates (September 1, 1950). The University of Chicago, Institute for Nuclear Studies, 1950. $15 \mathrm{p}$.

Arnold JR, Libby WF. 1951. Radiocarbon dates. Science 113:111-20.

Bacon CR. 1983. Eruptive history of Mount Mazama and Crater Lake Caldera, Cascade Range, U.S.A. Journal of Volcanology and Geothermal Research 18:57-115.

Bada JL, Helfman PM. 1975 Amino acid racemization dating of fossil bones. World Archaeology 7:160-83.

Bada JL, Schroeder RA, Carter GF. 1974. New evidence for the antiquity of man in North America deduced form aspartric acid racemization. Science 184:791-3.

Baumhoff M, Heizer, RF. 1965. Postglacial climate and archaeology in the desert west. In: Wright HE Jr, Frey DG, editors. The Qyaternary of the United States, Part I, geology. Princeton: Princeton University Press. p 697-707.

Bell R. 1951. Dendrochronology at the Kincaid site. In: Cole FC, editor. Kincaid: a prehistoric llinois metropolis. Chicago: University of Chicago Press. p 233-92.

Bell R. 1952. Denchronology in the Mississippi Valley. In: Griffin, JB, editor. Archeology of the Eastern United States. Chicago: University of Chicago Press. p 345-51.

Berger R, Libby WF. 1967. UCLA radiocarbon dates VI. 
Radiocarbon 9:477-504.

Berger R, Libby LM, editors. 1981. Radiocarbon and tritium. Volume 1. The publications of Willard Libby. Santa Monica: Geo Science Analytical Inc.

Berger R, Protsch R, Reynolds R, Rozaire R, Sackett JR. 1971. New radiocarbon dates based on bone collagen of California. Contributions of the California Archaeological Research Facility 12:43-49.

Betancourt JL, Long A, Donahue DJ, Jull AJT, Zabel TH. 1984. Native or alien? The case for North American Corispermum L. (Chenopodiaceae). Science 311:6535.

Bischoff JL, Childers, WM. 1979. Temperature calibration of amino acid racemization: age implications for the Yuha skeleton. Earth and Planetary Science Letters 45:172-80.

Bischoff JL, Merriam R, Childers WM, Protsch R. 1976. Antiquity of man in America indicated by radiometric dates on the Yuha burial site. Nature 261:128-9.

Breternitz DA, Swedlund AC, Anderson DC. 1971. An early burial from Gordon Creek, Colorado. American Antiquity 36:170-81.

Broecker WS, Olson EA, Bird J. 1959. Radiocarbon measurements on sample of known age. Nature 183 . 1582-4.

Burky RR, Kirner DL, Taylor RE, Hare PE, Southon JR. 1998. Radiocarbon dating of bone using gamma-carboxyglutamic acid and alpha-carboxyglycine (aminomalonate). Radiocarbon 40(1):11-20.

Byers DS, editor. 1967-1972. Prehistory of the Tehuacan Valley. 4 vol. Austin: University of Texas Press.

Campbell JM. 1965. Radiocarbon dating in far northern archaeology. In: Chatters RM, Olson EA, compliers. Proceedings of the Sixth International Conference Radiocarbon and Tritium Dating. Springfield (Virginia) Clearinghouse for Federal Scientific and Technical Information. p 179-86.

Chatters RM, Olson EA, compilers. 1965. Proceedings of the Sixth International Conference Radiocarbon and Tritium Dating [Conf-650652]. Springfield (Virginia): Clearinghouse for Federal Scientific and Technical Information. $784 \mathrm{p}$.

Chrisman D, MacNeish RS, Mavalwala J, Savage H. 1996. Late Pleistocene human friction skin prints from Pendejo Cave, New Mexico. American Antiquity 61: 357-76.

Clark JD. 1979. Radiocarbon dating and African archaeology. In: Berger R, Suess HE, editors. Radiocarbon dating. Berkeley: University of California Press. p $7-$ 31.

Collins MB. 1999. Reply to Fiedel, Part II. Discovering Archaeology [special report] 1(6):14-5.

Coe MD, Diehl RA. 1980. In the Land of the Olmec: the Archaeology of San Lorenzo Tenochititlan. 2 vols. Austin: University of Texas Press.

Conrad N, Asch DL, Asch NB, Elmore D, Gove H, Rubin M, Brown JA, Wiant MD, Farnsworth KB, Cook TG.
1984. Accelerator radiocarbon dating of evidence for prehistoric horticulture in Illinois. Nature 308:443-6.

Crook WW Jr, Harris RK. 1958. A Pleistocene campsite near Lewisville, Texas. American Antiquity 23:23346.

Daniel G. 1967. The origin and growth of archaeology. New York: Crowell. 298 p.

Dean, JS. 1978. Independent dating in archaeological analysis. In: Schiffer MB, editor. Advances in archaeological method and theory. New York: Academic Press. p 223-65.

Dick HW. 1965. Bat Cave. School of American Research Monograph No. 27.

Dillehay TD. 1989. Monte Verde: a late Pleistocene settlement in Chile 2: the archeological context. Washington DC: Smithsonian Institution Press.

Dillehay TD. 1997. Monte Verde: a Late Pleistocene settlement in Chile 1: the archeological context. Washington DC: Smithsonian Institution Press.

Dillehay TD, Meltzer, DJ, editors. 1991. The first americans: search and research. Boca Raton: CRC Press.

Dillehay TD, Pino M, Rossen J, Ocampo, C, Rivas P, Pollack D, Henderson G. 1999. Reply to Fiedel, Part 1. Discovering Archaeology [special report] 1(6):12-4.

Dincauze D. 1981. The Meadowcroft papers. Quaterly Review of Archaeology 2:(1):3-4.

Drucker P, Heizer RF, Squier RJ. 1957. Radiocarbon dates from La Venta, Tabasco. Science 126:72-3.

Ennis P, Noltmann EA, Hare PE, Slota PJ Jr, Payen LA, Prior CA, Taylor RE. 1986. Use of AMS analysis in the study of problems in aspartic acid racemization-deduced age estimates on bone. Radiocarbon 28(2B):539-46.

Fedick SL, Taube KA. 1992. The role of radiocarbon datging in Maya archaaeology: four decades of research. In: Taylor RE, Long A, Kra RS editors. Radiocarbon after four decades: an interdisciplinary perspective. New York: Springer-Verlag. p 403-20.

Fergusson GJ, Libby WF. 1963. UCLA radiocarbon dates II. Radiocarbon 5:1-22.

Fiedel SJ. 1999. Artifact Provenience at Monte Verde: confusion and contradictions. Discovering Archaeology [special report] 1(6):1-12.

Gittins GO. 1984. Radiocarbon chronometry and archaeological thought. Unpublished $\mathrm{PhD}$ dissertation. University of California, Los Angeles.

Green TJ, Cochran B, Fenton TW, Woods JC, Titmus GL, Tieszen L, Davis MA, Miller SJ. 1998. The Buhl Burial: a Paleoindian woman from southern Idaho. American Antiquity 63:457-67.

Griffin J. 1946. Cultural change and continuity in Eastern United States archaeology. In: Johnson F, editor. Man in northeastern North America. Papers of the Robert S. Peabody Foundation for Archaeology 3. p 37-95.

Griffin J. 1952. Archaeology of the eastern United States. Chicago: University of Chicago Press.

Griffin J. 1965. Radiocarbon dating and the cultural se- 
quence in the eastern United States. In: Chatters RM, Olson EA, compliers. Proceedings of the Sixth International Conference Radiocarbon and Tritium Dating. Springfield (Virginia): Clearinghouse for Federal Scientific and Technical Information. p 117-30.

Griffin J. 1967. Eastern North American archaeology: a summary. Science 156:175-91.

Griffin J. 1968. Northeast Asian and northwesern American ceramics. Proceedings of the VIIIth International Congress of Anthropological and Ethnological Sciences 3:327-30.

Griffin J. 1978. Eastern United States. In: Taylor RE, Meighan CW, editors. Chronologies in New World archaeology. New York: Academic Press. p 51-70.

Haas H, Holliday V, Stuckenrath R. 1986. Dating of Holocene stratigraphy with soluble and insoluble organic fractions at the Lubbock Lake archaeolopgy site, Texas: an ideal case study. Radiocarbon 28(2B):47385.

Hallet, DJ, Hills, LV, Clague JJ. 1997 New accelerator mass spectrometry radiocasrbon ages for the Mazama tephra layer from Kootenay National Park, British Columbia, Canada. Canadian Journal of Earth Sciences 34:1202-9.

Hard RJ, Roney JR. 1998. A massive terraced village complex in Chihuahua, Mexico, 3000 years before present. Science 279:1661-4.

Harrington MR. 1954. The oldest camp-fires. The Masterkey 28:233-4.

Harrington MR, Simpson RE. 1961. Tule Springs, Nevada with other evidence of Pleistocene man in North America. Southwest Museum Papers No. 18. Los Angeles: Southwest Museum.

Hart JP, Scarry C. 1999. The age of common beans (Phaseolus vulgaris) in the Northeastern United States. American Antiquity 64:653-8.

Haynes CV Jr. 1965. Carbon-14 dates and early man in the new world. In: Chatters RM, Olson EA, compilers. Proceedings of the Sixth International Conference on Radiocarbon and Tritium Dating. Springfield (Virginia): Clearinghouse for Federal Scientific and Technical Information. p 145-64.

Haynes CV Jr. 1980. Paleoindian charcoal from Meadowcroft Rockshelter: is contamination a problem? American Antiquity 45:582-587.

Haynes CV Jr. 1982. Were Clovis progenitors in Beringia? In: Hopkin DM, Matthews JV, Schweger CE, Young SB, editors. Paleoecology of Beringia. New York: Academic Press. p 383-98.

Haynes CV Jr. 1984. Stratigraphy and late Pleistocene extinction. In: Martin PS, Klein RG, editors. Quaternary extinctions: a prehistoric evolution. Tucson: University of Arizona Press.

Haynes CV Jr. 1988. Geofacts and fancy. Natural History 2/88:4-12.

Haynes CV Jr. 1991. Geoarchaeological and paleohydrological evidence for a Clovis-age drought in North
America and its bearing on extinction. Quaternary Research 35:438-50.

Haynes CV Jr, Agogino G. 1960. Geological significance of a new radiocarbon date from the Lindenmeir site. Denver Museum of Natural History Proceedings. Number 9. Denver: Denver Museum of Natural History. $23 \mathrm{p}$.

Haynes CV Jr, Doberenz AR, Allen JA. 1966. Geological and geochemical evidence concerning the antiquity of bone tools from Tule Springs, site 2, Clark County, Nevada. American Antiquity 31:517-21.

Hedges REM. 1997. Radiocarbon dating-50 years on. Education in Chemistry 27:157-159,164.

Hedges REM, Law IA. 1989. The radiocarbon dating of bone. Applied Geochemistry 4:233-49.

Hedges REM, Van Klinken GJ. 1992. A review of current approaches in the pretreatment of bone for radiocarbon dating by AMS. Radiocarbon 34(3):279-91.

Heizer RF, Brooks RA. 1965. Lewisville-ancient campsite or wood rat houses? Southwestern Journal of Anthropology 21:155-65.

Heizer RF, Hester TR. 1978. Great Basin. In: Taylor RE, Meighan CW, editors. Chronologies in New World Archaeology. New York: Academic Press. p 147-99.

Hester TR. 1973. Chronological ordering of Great Basin prehistory. University of California Archaeological Research Facility Contributions 17. Berkeley: University of California.

Holliday V, Johnson E. 1986. Re-evaluation of the first radiocarbon age for the Folsom culture. American Antiquity 51:332-8.

Irving WN. 1985. Context and chronology of early man in the Americas. Annual Review of Anthropology 14: 529-55.

Irving WN, Harrington CR. 1973. Upper Pleistocene radiocarbon-dated artifacts from the Northern Yukon. Science 179:335-40.

Johnson F. 1948. American Archaeology, 1947. American Journal of Archaeology 52:344-72.

Johnson F. 1950. American Archaeology, 1949. American Journal of Archaeology 54:235-53.

Johnson F. 1951. Introduction. Radiocarbon dating. Memoirs of the Society for American Archaeology 8: 1-3. (American Antiquity 17(1)[part 2]:1-3).

Johnson F. 1952. The significance of the dates for archaeology and geology. In: Libby WF, editor. Radiocarbon dating. Chicago: University of Chicago Press. p 97111.

Johnson F. 1955. Reflections upon the significance of radiocarbon dates. In: Libby WF, editor. Radiocarbon dating. Second edition. Chicago: University of Chicago Press. p 141-61.

Johnson F. 1965. The impact of radiocarbon dating upon archaeology. In: Chatters RM, Olson EA, compliers. Proceedings of the Sixth International Conference Radiocarbon and Tritium Dating. Springfield (Virginia): Clearinghouse for Federal Scientific and Technical In- 
formation. p 762-80.

Johnson F, MacNeish RS. 1972. Chronology of the Tehuacan Valley. In: Byers DS, editor. Prehistory of the Techuacan Valley, Volume 4. Austin: University of Texas Press.

Johnson F, Willis EH. 1970. Reconciliation of radiocarbon and sideral years in Meso-American chronology. In: Olsson IU, editor. Radiocarbon variations and $a b-$ solute chronology. Stockholm: Almqvist \& Wiksell. p 93-104.

Johnson F, Rainey F, Collier D, Flint RF. 1951. Radiocarbon dating, a summary. Radiocarbon dating. Memoirs of the Society for American Archaeology 8:59-63. [American Antiquity 17(1, part 2):59-63].

Kaufman TS. 1980. Early prehistory of the Clear Lake area, Lake County, California. PhD dissertation. University of California, Los Angeles.

Kelley DH. 1983. The Maya calendar correlation problem. In: Leventhal, RM, Lolata LM, editors. Civilization in the ancient Americas, essays in honor of Gordon R. Willey. Albuquerque: University of New Mexico Press. p 157-86.

Kirner, DL, Burky R, Selsor K, George D, Taylor RE, Southon JR. 1997. Dating the Spirit Cave Mummy: the value of reexamination. Nevada Historical Society Quarterly 40:54-6.

Kovar AJ. 1966. Problems in radiocarbon dating at Teotihuacan. American Antiquity 31:427-30.

Kulp JL, Feely HW, Tryon LE. 1951. Lamont natural radiocarbon measurements, I. Science 114:565-8.

Libby WF. 1946. Atmospheric Helium three and radiocarbon from cosmic radiation. Physical Review 69: 671-2.

Libby WF. 1951. Radiocarbon dates, II. Science 114: 291-6.

Libby WF. 1952. Radiocarbon dating. Chicago: The University of Chicago Press. 124 p.

Libby WF. 1954. Chicago radiocarbon dates V. Science 120:733-42.

Libby WF. 1955. Radiocarbon dating. 2nd edition. Chicago: The University of Chicago Press. 175 p.

Libby WF. 1967. History of radiocarbon dating. Radioactive dating and methods of low level counting. $\mathrm{Vi}$ enna: International Atomic Energy Agency. p 3-25.

Libby WF, Anderson EC, Arnold JR. 1949. Age determination by radiocarbon content: world wide assay of natural radiocarbon. Science 109:227-8.

Long A, Benz BF, Donahue DJ, Jull AJT, Toolin LJ. 1989. First direct AMS dates on early Maize from Tehuacán, Mexico. Radiocarbon 31(3):1035-40.

Lynch TF. 1990. Glacial-age man in South America: a critical review American Antiquity 55:12-36.

MacNeish RS. 1996. Federick Johnson 1904-1994 (obituary). American Antiquity 61:269-73.

Madson DB, Berry MS. 1975. A reassessment of northeastern Great Basin prehistory. American Antiquity 40:391-405
Mead JI. 1980. Is it really that old? A comment about the Meadowcroft Rockshelter "overview”. American Antiquity 45:579-83.

Meltzer DJ. 1989. Why don't we know when the first people came to North America? American Antiquity 54:471-90.

Meltzer DJ, Adovasio JM, Dillehay TD. 1994. On a Pleistocene human occupation at Pedra Furada, Brazil. Antiquity 68:695-714.

Meltzer DJ, Grayson DK, Ardile G, Barker AW, Dincauze DF, Haynes CV, Mena F, Nunez L, Stanford DJ. 1997. On the Pleistocene antiquity of Monte Verde, Southern Chile. American Antiquity 62:659-63.

Minnis PE. 1992. Earliest plant cultivation in the desert boarderlands of North America. In: Cowan CW, Watson PJ, editors. The origins of agriculture. Washington DC: Smithsonian Institution Press. p 121-41.

Nelson DE, Moreland, RE, Vogel, JS, Southern JR, Harington CR. 1986. New radiocarbon dates on artifacts from the northern Yukon Territory: Holocene not upper Pleistocene in age. Science 232:749-51.

Neustupny, E. 1970. The accuracy of radiocarbon dating. In: Olsson IU, editor. Radiocarbon variations and absolute chronology. Stockholm: Almqvist and Wiksell. p 23-34.

Olsson IU, editor. 1970. Radiocarbon variations and absolute chronology. Stockholm: Almqvist and Wiksell. $652 \mathrm{p}$.

Payen L, Taylor RE. 1977. Man and Pleistocene fauna at Potter Creek Cave, California. Journal of California Anthropology 3:51-8.

Payen LA. 1982. The pre-Clovis of North America: temporal and artifactual evidence. PhD dissertation. University of California, Riverside.

Payen LA, Rector CH, Ritter E, Taylor RE, Ericson JE. 1978. Comments on the Pleistocene age assignment and association of a human burial from the Yuha Desert, California. American Antiquity 43:448-53.

Phillips P, Ford J, Griffin JB. 1951. Archaeological survey in the lower Mississippi alluvial valley 19401947. Papers of the Peabody Museum of American Archaeology and Ethnology. Volume 25. Cambridge: Peabody Museum.

Rainey FG. 1941. Eskimo prehistory: the Okvik site on the Punuk Islands. American Museum of Natural History Anthropological Papers 37:453-569.

Ralph EK. 1965. Review of radiocarbon dates from Tikal and the Maya calendar correlation problem. American Antiquity 30:421-7.

Ralph EK. 1971. Carbon-14 dating. In: Michael HN, Ralph EK, editors. Dating techniques for the archaeologist. Cambridge: The MIT Press. p 1-48.

Renfrew C. 1974. Before civilization, the radiocarbon revolution and prehistoric Europe. New York: Alfred A. Knopf.

Riley TJ, Walz GR, Baries CJ, Fortier AC, Parker K. 1994. Accelerator mass spectrometry (AMS) dates 
confirm early Zea Mays in the Mississippi River Valley. American Antiquity 59:490-8.

Ritchie WA. 1969. The archaeology of New York State. Garden City: Natural History Press.

Roberts FHH. 1951. Radiocarbon dates and early man. In: Johnson F, assembler. Radiocarbon dating. Society for American Archaeology Memoirs 8:20-21. [American Antiquity 17,(1) part 2].

Rohn AH. 1978. American Southwest. In: Taylor RE, Meighan CW, editors. Chronologies in New World archaeology. New York: Academic Press. p 51-70.

Saatterthwaite L. 1956. Radiocarbon dates and the correltaion problem. American Antiquity 21:416-9.

Satterthwaite L, Ralph EK. 1960. New radiocarbon dates and the Maya correlation problem. American Antiquity 26:165-84.

Sears PB. 1932. The archaeology of environment in Eastern North America. American Anthropologist 34:610 22.

Simmons AH. 1986. New evidence for the early use of cultigens in the American southwest. American Antiquity 51:73-89.

Stafford TW, Duhamel RC, Haynes CV Jr, Brendel K. 1982. The isolation of proline and hydroyproline from fossil bone. Life Science 31:931-8.

Stafford TW, Jull AJT, Zabel TH, Donahue DJ, Duhamel RC, Brendel K, Haynes CV Jr, Bishoff JL, Payen LA, Taylor RE. 1984. Holocene age of the Yuha burial: direct radiocarabon determinations by accelerator mass spectrometry. Nature 308:446-7.

Stafford TW, Hare PE, Currie L, Jull AJT, Donahue DJ. 1990. Accuracy of North American human skeleton ages. Quaternary Research 34:111-20.

Stafford TW Jr, Hare PE, Currie L, Jull AJT, Donahue DJ. 1991. Accelerator radiocarbon dating at the molecular level. Journal of Archaeological Sciences 18: 35-72.

Stanford DJ. 1982. A critical review of archaeological evidence relating to the antiquity of human occupation of the New World. Smithsonian Contributions to Anthropology 30:202-18.

Stoltman J. 1978. Temporal models in prehistory: an example from Eastern North America. Current Anthropology 19:703-46.

Southon JR, Brown TA. 1995. The GISP2 ice core record of volcanism since 7000 BC: comment. Science 267: 256-7.

Suess HE. 1954. U.S. Geological Survey radiocarbon dates I. Science 120:467-73.

Tagg MD. 1996. Early cultigens from Fresnal Shelter, Southeastern New Mexico. American Antiquity 61: 311-24.

Tankersley KB, Munson CA. 1992. Comments on the Meadowcroft Rockshelter radiocarbon chronology and the recognition of coal contaminants. American Antiquity 57:321-6.

Taylor RE. 1975. UCR radiocarbon dates II. Radiocar- bon 17(3):396-406.

Taylor RE. 1978. Radiocarbon dating: an archaeological perspective. In: Carter GF, editor. Archaeological chemistry II. Washington: American Chemical Society. p 33-69.

Taylor RE. 1987. Radiocarbon dating: an archaeological perspective. Orlando: Academic Press. 212 p.

Taylor RE. 1991. Frameworks for dating the late Pleistocene peopling of the Americas. In: Dillehay TD, Meltzer DJ, editors. The first Americans: search and research. Boca Raton: CRC Press. p 77-112.

Taylor RE. 1992. Radioisotope dating by accelerator mass spectrometry: archaeological and paleoanthropological perspectives. In: Goksu HY, Obserhofer M, Regulla D, editors. Scientific dating methods. Dordrecht (Netherlands): Kluwer Academic Publishers. p 37-54.

Taylor RE. 1994. Radiocarbon dating of bone using accelerator mass spectrometry: current discussions and future directions. In: Bonnickson R, Steele DG, eds. Method and theory for investigating the peopling of the Americas. Corvallas: Oregon State University, Center for the Study of the First Americans. p 27-44.

Taylor RE. 1997. Radiocarbon dating. In: Taylor RE, Aitken MJ, editors. Chronometric dating in archaeology. New York: Plenum Press. p 65-96.

Taylor RE. 2000a. Archaeometry and the "Two Cultures Effect" in American anthropological archaeology. In: Rice P, Rice D, editors. The past and future of anthropologcial archaeometry. Carbondale: Southern Illinois University.

Taylor RE. 2000b. Fifty years of radiocarbon dating. American Scientist 88(1):60-7.

Taylor RE, Payen LA, Gerow B, Donahue DJ, Zabel TH, Jull AJT, Damon PE. 1983. Middle Holocene age of the Sunnyvale human skeleton. Science 220:1271-3.

Taylor RE, Payen LA, Prior CA, Slota PJ Jr, Gillespie R, Gowlett JAJ, Hedges REB, Jull AJT, Zabel TH, Donahue DJ, Berger R. 1985. Major revisions in the Pleistocene age assignments for North American human skeletons by ${ }^{14} \mathrm{C}$ accelerator mass spectrometry: none older than $11,000{ }^{14} \mathrm{C}$ years B.P. American Antiquity 50:136-40.

Taylor RE, Payen LA, Slota PJ Jr. 1992. The age of the Calaveras Skull: dating the "Piltdown Man" of the New World. American Antiquity 57:269-75.

Taylor RE, Hare PE, Prior CA, Kirner DL, Wan L, Burky RR. 1995. Radiocarbon dating of biochemically characterized hair. Radiocarbon 37(2):319-30.

Taylor RE, Haynes CV Jr, Stuiver, M. 1996. Clovis and Folsom age estimates: stratigraphic context and radiocarbon calibration. Antiquity 70:515-25.

Taylor RE, Kirner DL, Southon JR, Chatters JC. 1998. Radiocarbon age of Kennewick Man. Science 280: 1171-2.

Taylor RE, Haynes CV Jr, Kirner DL, Southon JR. 1999. Analysis of modern organics at Monte Verde, Chile: 
no evidence for a local reservoir effect. American Antiquity 64:455-60.

Thompson JES. 1960. Maya hieroglyphic writing: an introduction. Norman: University of Oklahoma Press.

Wilke PJ. 1978. Cairn burials of the California deserts. American Antiquity 43:444-8.

Willey GR, Phillips P. 1958. Method and theory in American archaeology. Chicago: University of Chicago Press.

Wilmsen EN. 1965. An outline of early man studies in the
United States. American Antiquity 31:172-92.

Wormington HM. 1957. Ancient man in North America. Denver: Denver Museum of Natural History.

Wormington HM, Ellis D, editors. 1967. Pleistocene studies in southern Nevada. Nevada State Museum Anthropological Papers, No. 13. Carson City: Nevada State Museum. 409 p.

Zdanowicz CM, Zielinski GA, Germani MS. 1999. Mount Mazama eruption: caldendrical age verified and atmospheric impact assessed. Geology 27:621-4. 